\title{
Do Children Still Adore Local Fairy Tales?
}

\author{
Sharina Munggaraning Westhisi ${ }^{1, *}$, Dian Handayani ${ }^{2}$ \\ ${ }^{1}$ IKIP Siliwangi, Terusan Jenderal Sudirman, Cimahi 40526, Indonesia \\ ${ }^{2}$ Purwakarta Nature School, Kp Sindang Reret Ds Benteng Campaka, Purwakarta,Indonesia \\ *Corresponding author. Email: sharina@ikipsiliwangi.ac.id
}

\begin{abstract}
Reading assists an individual to obtain knowledge and provides enjoyment for children's literacy development. However, promoting literacy through a local fairy tale is challenging since children tend to be familiar with fairy tales from other countries, such as Cinderella or Snow White. Thus, proper teaching media are required to introduce a local fairy tale for children. This study used a qualitative descriptive method in order to investigate a mini library developed by social communities in Purwakarta, Indonesia. Five tutors were involved to be interviewed and study documentation was employed regarding storytelling preparation and implementation. It showed that they adapted and developed ideas of a local fairy tale to engage children in learning instructions to be more familiar with local fairy tales. During the implementation, tutors created various properties in storytelling activities. Besides, the story was delivered constantly. To sum up, story adjustment is required to boost children's interests in preserving the local culture through literacy.
\end{abstract}

Keywords: Children's literacy, local fairy tale, teaching instructions.

\section{INTRODUCTION}

Literacy is an aspect of national assessment which will be tested in 2021 by the government of Indonesia, to replace national exams for students in elementary school up to senior high school. It concludes the ability to analyse and to comprehend the text through language. Reading becomes essential to enhance literacy skills for students. The result of Programme Internationale of Student Assessment (PISA) in 2018, which is a programme of Organization for Economic Co-operation Development (OECD), Indonesia is in level 1 of level 6 for reading performance. It indicates that reading activities for students are still low [1]. To improve the score of student's reading performance in PISA, the government of Indonesia has various programmes regarding literacy which are conducted in formal, nonformal and informal education.

Literacy has a strong connection with reading. It is a linguistic activity that involves knowledge about the words' structure [2]. Children's first knowledge of literacy requires appropriate exposures from various resources. They are books, movies, games, teachers, parents or peers. Reading activity could occur in a formal setting and an informal setting, in order to create a joyful ambience to do it.

In regard to literacy, it could be introduced early in life and long before children get the formal literacy instruction in primary school [3]. It can be done through several interesting activities at home, school or community environment. Home literacy models could be employed to find out the children's engagement in literacy activities at home since children with stronger foundation of early literacy skills in kindergarten read independently when they go to primary school rather than the children who do not have a sturdy foundation of literacy [4]. Moreover, literacy activities are often found at school through storytelling.

Storytelling is a common and well-known method in Early Childhood Education (ECE) since it provides some aspects that grab attention of children, such as visualization that helps children to comprehend the story and the activity could be an aesthetic literacy [5]. Additionally, it has influenced teachers and parents to deliver the stories in an entertaining way for children. It might be a tool for teachers to teach positive characters by providing stories which have moral values and to introduce the local culture, in order to engage the children's awareness of cultures [6], [7].

Some of studies conducted related to storytelling activities and local culture, for instance the usage of digital to deliver the story on Sundanese culture which was successful to make the children enjoyed it and the introduction of a local character such as Wayang Golek as a part of local culture to teach cultural values as an identity of a particular community [8], [9]. 
Nowadays, children require enormous influences by surroundings in enhancing literacy development. Community environment has significant roles to influence children in improving literacy skills [10]. Unfortunately, parents and teachers are still unaware about community services which can support and assist children's literacy development [11]. Thus, community services are needed to assist parents and teachers in fostering children to achieve literacy development optimally.

Teaching practices through the digital era could be very valuable to retrieve countless stories across the country. It opens the access widely for children to acquire stories by clicking the button. Zhussupova [7] believed that implementation of children's literacy through storytelling could be done by the teachers who are able to integrate the storytelling activities with technology to be more attractive for children, meaning that, it might encourage children become more familiar with fairy tales from abroad such as Cinderella, Snow White, Red Little Riding Hood, and so on. It occurred since people could access readily. Unintentionally, they do not recognize their own local fairy tales due to limited resources that provide a local fairy tale. Thus, the study aims to unpack the teaching practice through storytelling by delivering a local fairy tale for children.

\section{METHOD}

Qualitative descriptive method was used in this article which involved five tutors who are the volunteers in one of the mini libraries located in Purwakarta. The online interview was conducted due to pandemic situation to obtain the data, regarding preparation and implementation of learning activities. In addition, study documentation was equipped to analyse the storybook entitled "Jonggrang Kaliputung" as a medium for storytelling activity. Then, thematic analysis was employed to unpack two themes which consist of learning preparation for children's literacy activities and another one is the implementation of children's literacy activities through storytelling of a local fairy tale.

\section{RESULT AND DISCUSSION}

\subsection{Story Telling Preparation of Children's Literacy}

Storytelling is a common activity used by the teachers and parents as one of teaching tools to improve children's literacy development. Story becomes a part of children's world since they love listening to or telling a story in their early life. In ECE, a story is a central role of teaching practice because it consists of motivation, meaning, fluency, language awareness, stimulus for speaking and writing and communication [12]. There are some aspects that should be prepared by the tutor beforehand storytelling. They are contents and packaging.

First, contents are a core of storytelling activity. The tutor should select a story, as a content, which is relevant and contextual with the children, meaning that the tutor picked the story which is suitable with their age and social culture. The tutors prefer to tell a story about a local fairy tale that comes from Purwakarta. They believe that children are required to preserve the local culture and to get character values through a local fairy tale. It is in line with Ramdhani, Yuliastri, Sari, and Hasriah [13] stating that a local fairy tale provides some character values such as responsibility, independence, honesty, religion and cooperation. Furthermore, storytelling of a local fairy tale might be a unique way to improve children's literacy and to present the beautiful local cultures since it might engage children to enjoy, be interested in and active during storytelling [12].

Several components should be prepared by the tutors. They are theme, contents, media and mental. First, the theme is a guideline for the tutors to select the contents, for instance getting to know the place in Purwakarta which has the potential to be a tourist destination. Second, they obtained deep information about a place which has a story behind it in order to assist the children in improving literacy development and cultural awareness at once. Then, they prepared the media made by themselves. They have a solid team teaching to develop the various media for delivering a local fairy tale in order to be more attractive and assist the children to comprehend it.

Preparing before storytelling was flexible. They do not have a lesson plan, yet they confess that flexibility gives them a freedom to be more creative in developing the ideas of storytelling activity. Lastly, mental preparation is needed. The tutors explained that nervousness and anxiety occurred in a particular situation while storytelling. Typically, it happens when the teacher is not well-prepared for materials, activities or teaching media. Regarding storytelling, the tutors should remember the story by doing several ways such as read the story in a few minutes and practise how to retell it, highlight the key points of a story and remember the personality of the main character [12]. Thus, the storyteller's feeling has a connection with preparation itself.

Second, packaging means the book as a medium for storytelling activity. The mini library in Purwakarta is a place founded and developed by social workers in a community service. They are working with Sundanese subject teacher deliberation $(M G M P)$ in Purwakarta. They adapted a book made by a teacher who is a member of MGMP. The book, entitled "Jonggrang Kaliputung: Legenda Gunung Bongkok di Purwakarta", was written in Sundanese language which has been translated into Bahasa Indonesia by tutors. 
The purpose of the translation process is to get closer to the children in introducing a local culture through a story. One tutor believed that by telling this story, children are able to recognize one of the natural tourist destinations in Purwakarta. Moreover, another reason for the translation process is to assist children to comprehend the story and could visualize the main character. It was confirmed that there was a relationship between the visual and the culture they captured, yet the illustrator should be more careful and detailed in portraying the culture in order to avoid misinterpretation [6]. The packaging of a local fairy tale could be seen below.

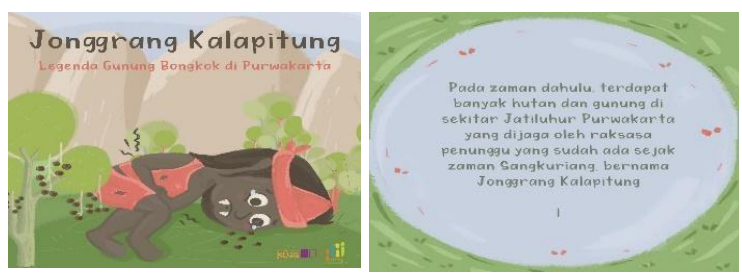

Figure 1 Book of Jonggrang Kalapitung

\subsection{Storytelling Implementation of Children's Literacy}

The implementation focuses on how the tutors do a storytelling and children's responses to it. There is no specific time for the tutors do the storytelling activity, could be once or twice a week, since the teaching practice is adaptable. However, the tutor said that they have structured learning activities such as they do the icebreaking for opening, go to the main activity which is storytelling and closing activity includes discussion or reflection about the story. Though, children were not in a formal setting, the tutors set and follow the learning activity which is child friendly, for instance providing the games and fairy tales [14].

Implementation of storytelling relates to how the tutors tell a story in an entertained way. First, they need to set the place before storytelling. They created a small group of children and sat down comfortably. The seating arrangement might be in a U-shape with a distance in proper [12]. It helps the tutors to use the voice not too loud or not too soft when delivering the story. Second, the tutors should make numerous intonations in order to distinguish narrative readings and dialogue in the story. Besides, articulation should be clear also. It is very essential to use proper articulation while delivering a story to children since this activity is used to improve literacy skills and the way how to communicate with others. Additionally, the literacy media are able to enhance the social interaction of children with peers or adults [15], meaning that effective communication constructs the positive social interaction.

During the implementation, the tutors stated that they told the same story more than once. It is believed that children will be more familiar with and comprehend the story it was told repeatedly, for instance Hebb repetition learning is able to support and facilitate children to develop children's literacy, such as and reading [16]. In addition, during storytelling the tutor repeated the character's name and some words as a new vocabulary such as jengkol. This repetition assists the children to acknowledge the new vocabulary. In line with this, Schwab and Lew-Williams [17] mentioned that repetition across successive sentences accommodates young children to learn words.

Children's enthusiasm emerges while displaying the story with colourful pictures. Yet, the tutor's barrier is about how to get back the children's attention. It might have happened since the tutors mentioned beforehand that they told the same story more than once with the same media. Using various media could provide a new ambience for children even though storytelling with the same story. It might create online media as well such as creating animation movies from the book made since the online media is very popular and it has positive effects for children's literacy skills [18]. Therefore, storytelling could be implemented successfully by considering the teacher or tutor skills in delivering the story and creating various media (online or offline) in order to avoid the children's boredom in developing literacy skills and preserving the local culture.

\section{CONCLUSION}

Children's literacy skill is required to develop through reading or listening to a story. Storytelling is a first step for children to fall in love with literacy. Besides, there are countless stories that could be told, for instance a local fairy tale that is still adored by children. The literacy activities required an established preparation by forming a team teaching to select the story and to develop the media. In addition, enthusiasm of children will be increased when the tutor or teacher could provide several media and techniques to deliver the story such as combining the games and fairy tales. Therefore, the literacy activities facilitate children's needs and interests to enhance their literacy skills and to improve their cultural awareness.

\section{ACKNOWLEDGMENT}

The author would like to thank the tutors at KLUG Purwakarta for their time, sharing experiences of teaching literacy for children, thus this study could be done smoothly.

\section{REFERENCES}

[1] Schleicher A. PISA 2018: Insight and interpretations [Internet]. Singapore: Organisation for Economic Cooperation and Development (OECD); 2019 [cited 2020 November 3]. Available from: https://www. oecd.org. 
[2] Tabors PO, Snow CE. Young bilingual children and literacy development. In: Neuman, Dickinson, editors. Handbook of Early Literacy Research. New York: Guilford Press; 2001. pp.159-178.

[3] Teale WH, Sulzby E. Emergent literacy as a perspective for examining how young children become writers and readers. In: Teale H, Sulzby E, editors. Emergent literacy: Writing and reading. Norwood, NJ: Ablex; 1986. pp.7-25.

[4] Silinskas G, Sénéchal M, Torppa M, Lerkkanen MK. Home literacy activities and children's reading skills, independent reading, and interest in literacy activities from kindergarten to grade 2 . Frontiers in Psychology [Internet]. 2020. [cited 2020 November 14];11:1-15. Available from: https://www. frontiersin.org/articles/10.3389/fpsyg.2020.01508/f ull DOI: 10.3389/fpsyg.2020.01508.

[5] Agosto DE. Why storytelling matters: Unveiling the literacy benefits of storytelling. Children and Libraries. 2016;14(2):21-26.

[6] Sá G, Menegazzi D, Caruso AP, Sylla C. Visual Development Processes for a Multicultural Storytelling Tool. In Proceedings of Confia [Internet]. 2019. [cited 2020 October 5]. Available from: https://www.researchgate.net/publication/333 295702_Visual_Development_Processes_for_a_Mu lticultural_Storytelling_Tool.

[7] Zhussupova RF. Exploring digital storytelling on cultural issues at the English lessons in multilingual classrooms. European Journal of Language and Literature [Internet]. 2017;3(1):22-30. Available from: http://journals.euser.org/index.php /ejls/article /view/1916.

[8] Ayuningtyas O, Effendy V, Kaburuan E. User Interface modelling by implementing storytelling on Sudanese cultural introduction media for early childhood using child-centred design methods. In IOP Conference Series: Materials Science and Engineering [Internet]. 2018;434(1):1-7. Available from: https://iopscience.iop.org/article/10.1088/175 7-899X/434/1/012278/meta.

[9] Halimah L, Arifin RR, Yuliariatiningsih MS, Abdillah F, Sutini A. Storytelling through "Wayang Golek" puppet show: Practical ways in incorporating character education in early childhood. Cogent Education [Internet]. 2020;7(1):1-12. Available from: https://www.tandfonline.com/doi/full/10.108 0/2331186X.2020.1794495. DOI: https://doi.org/10 .1080/2331186X.2020.1794495.

[10] Wijaya AW, Indasari SR, Samosir F, Petrus S. The roles of parents and community in supporting children's literacy development. In International Conference on Early Childhood Education and Parenting 2009 (ECEP 2019) [Internet]. 2020;454:27-31. Available from: https://www. atlantis-press.com/proceedings/ecep-19/125943186.
[11]López MM. Linking community literacies to critical literacies through community language and literacy mapping. Teaching and Teacher Education [Internet]. 2020;87:1-9. Available from: https:// www.sciencedirect.com/science/article/abs/pii/S074 2051X19307954

[12] Wright A. Storytelling with children. Oxford: Oxford University Press; 1998.

[13]Ramdhani S, Yuliastri NA, Sari SD, Hasriah S. Penanaman nilai-nilai karakter melalui kegiatan story telling dengan menggunakan cerita rakyat sasak pada anak usia dini. Jurnal Obsesi: Jurnal Pendidikan Anak Usia Dini [Internet]. 2019;3(1):153-160. Available from:https://obsesi. or.id/index.php/obsesi/article/view/108.

[14] Muravevskaia E, Tavassoli F, Gardner-McCune C. Developing children's cultural awareness and empathy through games and fairy tales. In Proceedings of the 15th International Conference on Interaction Design and Children. 2016;701-706. Available from: http://dx.doi.org/10.1145/2930674. 2935998.

[15] Aarsand P, Melander H. Appropriation through guided participation: Media literacy in children' s everyday lives. Discourse, Context \& Media [Internet]. 2016. [cited 2020 October 15];12:20-31. Available from: https://www.sciencedirect.com/ science/article/abs/pii/S2211695816300186.

[16] Attout, L, Ordonez M, Szmalec A, Majerus S. The developmental neural substrates of Hebb repetition learning and their link with reading ability. Human Brain Mapping [Internet]. 2020;41(14):3956-3969. Available from: https://onlinelibrary.wiley.com /doi /full/10.1002/hbm.25099. DOI:10.1002/hbm.25099.

[17] Schwab JF, Lew-Williams C. Repetition across successive sentences facilitates young children's word learning. Developmental Psychology [Internet] 2016;52(6):879-886. Available from: https:// pubmed.ncbi.nlm.nih.gov/27148781/. DOI: 10.1037 /dev0000125.

[18] Rahimi M, Yadollahi S. Effects of offline vs online digital storytelling on the development of EFL learners' literacy skills. Cogent Education. 2017;4(1):1-13. Available from: https://www .tandfonline.com/doi/full/10.1080/2331186X.2017. 1285531. DOI: http://dx.doi.org/10.1080/2331186X .2017 .1285531 . 